\title{
Öldürmenin Otobiyografisi: Gerçek Easterman Kim? Sosyal Yapisalcı Bir Yaklaşım Olan Anlatı Psikolojisinin İzinde Otobiyografik Performans
}

\section{T.Gözde PELİSTER*}

Özet

Bir sosyal yapısalcı yaklaşım olarak kabul edilen anlatı psikolojisi benliği zaman, anlatı ve yeniden yaratım süreçleriyle ilişkilendirmiştir. Bu süreçlerin anlatı türünde temsili olan otobiyografi ise tiyatro çalışmalarında geleneksel gerçek yaşam öyküsünün sınırlarını aşıp, kurgusal edimsel otobiyografik biçimlere evrilmiştir. Anthony Horrowitz'in Ermişler ya da Günahkarlar oyunu bu yeni yaklaşımın boyutlarının gözlemlenebileceği bir metindir. Gerçek öznenin, geçmişin yardımıyla şimdiyi kurmaya çalışmasına ilginç bir örnektir.

Anahtar Sözcükler: Benlik, otobiyografi, anlatı psikolojisi, Easterman, Anthony Horrowitz.

The Autobiography of Killing: which one is Real Easterman? The Autobiographic Performance On the Track of Narrative Psychology as a Social Constructionist Approach

\section{Abstract}

Narrative psychology as a social constructionist approach, attempts to associate the self to time, narrative and reconstruction processes. Autobiography being represented in narrative genre, has been evolved to performative autobiographic morphologies as expanding the boundaries of real life-story. Anthony Horrowitz's Mindgame is a text in which the characteristics of this new approach could be analysed. It's an interesting example for a subject who tries to construct a present with the help of the past.

Keywords: Self, Autobiography, Narrative Psychology, Easterman, Anthony Horowitz. 


\section{Giriş}

Geçtiğimiz yirmi yılda, psikolojide benlik algısının otobiyografiye bağlı oluşu kabul edilen bir prensibe dönüşmüştür (Neisser, 1986; Brewer, 1988; Ochs \& Capps, 1991). Sosyal yapısalcı yaklaşımların benlik, kimlik ve ilişki deneyimlerinin sözel ve kültürel olarak yapılandığını iddia ederek, psikolojinin alanına girmelerinin üzerinden on beş yıla yakın süre geçmiştir (Crossley, 2000: 527). Bu makalenin amacı, öncelikle sosyal yapısalcı bir yaklaşım olan anlatı psikolojisinin hikaye oluşturma ve varolma üzerindeki etkisini ortaya koymaktır. Ardından bu bağlamda otobiyografinin işlevini performansla ilişkilendirerek Anthony Horrowitz'in Ermişler ya da Günahkarlar oyunundaki Styler, Easterman ve Farquhar karakterleri üçgeninde tartışmaktır. Bu tartışmanın, anlatı psikolojisinin metinlerle olan ilişkisini ortaya koyarken, otobiyografinin gerçek insanlar gibi kurgu karakterlerin şekillenmesi üzerindeki etkisini de gösterebileceği düşünülmektedir. Kastedilen şekillenmenin aktörlerinden biri de performansın kendisidir. Tiyatroda kurgu karakterlerin kişisel bir hikayenin anlatıcıları olarak, -kendi yaşam öykülerini anlatmak zorunda olmadıkları halde- her birinin otobiyografik bir performans sergileyebilecekleri anlamına gelmektedir. Bu iddiayı geçerli kılmak için öncelikle anlatı psikolojisi ve otobiyografi ile ilgili kuramsal bir çerçeve çizmek gerekecektir.

\section{Benlik ve Kimlik üzerine Kuramsal Yola Çıkış}

İnsan yaşamı öyküsel bir yapı olarak değerlendirilebilir. Bu kavramsallaştırmanın temelinde insanın zaman algısı ve bu algıya göre yaşamını şekillendirmesi yatmaktadır. Zaman algısı kişiyi, yaşamını belli bir zamanda, şekilde ve düzende yaşaması için yönlendirmektedir. Bu zaman algısı çok büyük bir kırılma anı yani travma olmaksızın ayrıntılar dışında değişmeden yaşamı düzenlemektedir. Fakat yaşanan büyük bir travmanın sonucu insanın psikolojik olarak bir kırılma yaşadığı ve bunun sonucunda da tüm yaşam algısında bir çeşit zedelenme yaşadığı düşünülmektedir. Bu da kişinin yaşamsal bütünlüğünün, çevresiyle ilişkilenme ve düşünme şeklinin büyük bir değişikliğe uğradığı anlamına gelecektir. Horowitz'in oyunundaki Easterman karakterinde de görüleceği gibi, travmatik olaylar sonucu de- ğişen algı ya da daha ileri olarak hafızayı yitirme durumu kişinin benliğini tamamen yitirmesine sebep olmaktadır. Böylece kişi benliğini yeniden yapılandırmak için bir yaşam öyküsüne ihtiyaç duymaktadır. Diğer insanların yaşam rutinlerinden uzaklaşmakta, kendisine ait ve muhtemelen bir türlü düzene girmeyen bir gerçekliğe hapsolmaktadır.

Benlik ve kimlik üzerine çalışan sosyal yapısalcılık, toplum ve kişilik psikolojisine dahil olan çok daha geleneksel bazı yaklaşımların içinde kabul edilmektedir. Bu yaklaşımlar davranışsal, insani ve psikanalitik/psikodinamik yaklaşımlardır (Potter \& Wetherell, 1987). En bilinen sosyal yapısalcı yaklaşımların başında söylem analizi, feminist psikolojik yaklaşımlar, postyapısalcı/postmodernist yaklaşımlar ve retorik temelli yaklaşımlar gelmektedir. Bahsi geçen yaklaşımların ortak olarak üzerinde anlaştıkları şey, benliğin doğadaki herhangi bir nesne ya da varlık gibi keşfedilip tarif edilebileceğidir. Fakat bu tarif dille yapıldığından, gerçeğin dil yoluyla anlatılıp yorumlanırken, gerçekliğini büyük oranda yitirmesi bir problem olarak görülmektedir. Sosyal yapısalcılar dil ile benlik yapı sökümü arasında oldukça kuvvetli bir bağ olduğunu düşünmektedir. Ayrıca insan doğası ve kişisel deneyimlerle ilgili evrensel çıkarımlarda bulunmanın imkansıza yakın olduğunu iddia etmektedirler. Çünkü deneyimler tarihsel ve kültürel olarak değişkenlik göstermektedir. İşte bu bütünlük ve süreklilik eksikliği aynı zamanda post-modernistleri de 'öznenin ölümünü’ ilan etmek zorunda bırakan eksikliktir. Postmodernistler eğer tarif edilecek bir benlik yoksa benliğe sahip olunamıyorsa benlik kavramının terk edilmesini salık vermişlerdir. İşte sosyal yapısalcı söylem analistleri de geleneksel, merkezi ve bütünlüklü bir benlik varsayımını bu bağlamda reddetmek zorunda kalmaktadırlar (Crossley, 2000: 529).

\section{Benliğin Öyküsel Deneyimlenişi}

İnsan yaşamının öyküsel bir yapı olarak değerlendirilmesinin temelinde zaman algısının olduğu ifade edilmişti. Zamanın düzenleyici özelliğinin insan yaşamının öyküsünü anlamlı kıldığı vurgulanmıştı. Kişinin yaşam öyküsünden parçalar, kişisel zamanın içinde ve kişinin hafızasında depolanmaktadır. Zaman ise bu öyküye doğru bir sıralama 
vermektedir. Polkinghorne (1988: 4) anlam dünyası için zamanın yanı sıra geçiciliği de vurgulamıştır. Bu geçiciliği ise eylem ile ilişkilendirmiştir. Ayrıca ilişkilerin ve bağlantıların da yaşam öyküsünün anlamlı sıralamasına önemli katkıda bulunduğunu söylemiştir. İnsanın ilişkiler ve bağlantılar yoluyla, olayları hatırlayışı ve yorumlayışının değiştiğini ifade etmiştir.

Polkinghorne'nun yaklaşımı kişinin yaşam öyküsünü oluşturan sıralı anlam dünyasını algılama şeklinin değişkenliğinin, yaşam öyküsünün gerçekliğinin değişmesi sonucuna varılmasına sebep olmaktadır. Bunun yanı sıra Sarbin ise 'anlatısal prensip' olarak adlandırdığı hipotezinde bir öykünün insanların dünyevi boyutu olan eylemlerinin sembolize edilmiş tanımı olduğunu söylemiştir. Öykünün bir başlangıcı, ortası ve sonu vardır. Sarbin'e (1986: 3) göre öykü, plan olarak adlandırılan belirli eylem paternlerinden oluşmaktadır ve anlatı, insan eylemleri için bir düzenleyici prensiptir. Charles Taylor ise insanın benlik anlayışının diğer insanlar ve ahlakla ilintili olduğu iddiasını savunmuştur. Taylor’a göre insan, içinde bulunduğu toplumla etkileşim halindedir. Benlik ve ahlak arasındaki bağlantı 'iyi' olarak tanımlanan şeylerle bağlantılı hissetme arzusudur. Taylor, bu arzunun kaynağının da doğal olarak içinde yaşanılan toplum olduğunu savunmuştur. Bu durum kişinin yaşadığı hayatın nasıl bir hayat olduğunu ve nasıl bir hayatın yaşamaya değer olduğunu sorgulamasına sebep olmaktadır. Taylor, işte bu sorgulama sonucu neyin iyi olduğuyla ilgili oluşan cevapların toplumların kültürel yapısı doğrultusunda şekillendiğine inanmaktadır. Taylor'a göre mitler, hikayeler ve ritüeller toplumun iyi olanla kurduğu bağlantıları o toplumun üyelerine anlattığı öykülerdir (1989: 39-91).

Bir başka kuramcı Carr (1986) ise insan deneyiminin gerçekliğinin öyküsel ya da hikaye anlatıcı olarak karakterize edilebileceğini söylemiştir. Carr, Edmund Husserl'in insanların zamanı sıradan bir biçimde algıladığına dayanan zaman fenomenolojisine dayanmaktadır. Husserl'in insan deneyimlerini pasif, aktif ve benliğini/yaşamı deneyimleme olarak üç seviyeye ayırdığı modelde her seviyenin kendine özgü zamansal bir yapı olduğunu iddia etmiştir (Bruner, 1990). Husserl'e göre insan şimdiyi hiçbir zaman deneyimleyemez. Ancak geçmişe ve muhtemel gelecek ihtimallerine referans vererek yaşam olarak adlandırılan benlik bilincinin içinde yer alabilir.

Carr, Husserl'in tartışmasını, zamanın yani yaşamın deneyimlenmesinin "sanat ve yaşamda olan anlatının eylem yapısına” (1986: 74) benzediğini, bunun da başlangıç, orta ve son olarak planlanacak öyküsel bir yapı olduğunu söylemiştir. Carr, bir anlatıdaki giriş, gelişme ve sonucu karşılayan bu modeli insan yaşamının deneyimlenmesinin de kaynağı olarak kabul etmiştir. Edebi kuramcı Paul Ricoeur (1986: 85) da zamanın ancak anlatı sayesinde insanın benliğine evrilebileceğini söyleyerek Carr'ın yaklaşımını desteklemiştir. Ricoeur, anlatılan her öyküde iki çeşit zaman olduğunu iddia etmiştir. Biri olayları belli bir sırayla anlatan ve bir adım sonrasında ne olduğunu merak ettiren kronolojik olaylardır. Bir diğeri ise bütünlük, zirve ve kapanış özellikleriyle şekillenen bir zamandır. İkinci zamanın özelliği değişebilir oluşudur. Öykü geliştikçe olayların belli bir sırada, bütünlüklü bir biçimde dizildiği ve aralarında anlamlı bir ilişki oluşan zamandır. Ricoeur, insanın olayları kısa ve uzun dönem olarak bu biçimde deneyimleyişini öykülendirme süreci olarak adlandırmıştır. Kısaca Ricoeur'e göre şimdiyi deneyimlememiz ancak ilintili hatıralar aracılığıyla mümkün olabilmektedir. Yaşam öyküsü ancak geçmiş ve şimdinin bütünlüklü öyküsel ilişkisiyle ve bununla bağlantılı bir gelecek perspektifiyle oluşmaktadır (1991: 21).

Kişinin aktif ve pasif deneyimlerinden oluştuğu kabul edilen bir yapının yaşam öyküsü kavramıyla doğrudan ilişkisi açıktır. "Bu yapı birbirinden ayrı hikayeleri bir araya getirmenin de ötesinde, bu hikayeleri beni olarak şekillendirip aralarında bağlantılar inşa edilmesine bağlıdır” (Carr, 1986: 75). Carr’ın önerdiği, özellikle uzun dönem hatıraları da belli bir bütünlükte tutarak aktif ve pasif deneyimleri öyküleştiren yapı, tam manasıyla otobiyografi sürecini tanımlamaktadır. Ricoeur'ün insanın ancak yaşam öyküsünü anlatarak var olabileceğini temsilen belirlediği öyküsel kimliğini (1986: 132) Carr "yaşamlar yaşanırken anlatılır ve anlatılırken yaşanır” (1986: 61) sözleriyle doğrulamıştır. Bu gündelik yaşantımızda deneyimlerimiz içinde bizi biz yapan eylem algısıdır. 
Öyküleme, bu eylem algısıyla zamanın geçiciliğine şekil vermekte ve kişinin benliğini olduğu gibi algılamasına yardımcı olmaktadır. Ayrıca bu algılama sözle ifade edilmek zorunda değildir. Aslında "tıpkı bir öykü anlatıcısı gibi zamanı aşmaya ve öyküsel eylem içinde olayların akışını ileri geri giderek bir araya gelişini domine etmeye girişiyorum" (1986: 62) der Carr. Ayrıca tüm deneyimlerin anlamlı bir bütünün temsili oluşunun da kişiyi öykülere bağlı tuttuğu söylenebilir. Kişinin deneyimlerine bir anlam verebilmesi, bu deneyimlerin anlatılası deneyimler olduğunu düşünmesine sebep olmaktadır. Dolayısıyla bir arada bir şey ifade eden olaylar hikayenin bütününü oluşturmaktadır. Son olarak "öykü anlatıcısının zamanın ötesine geçmek değil, zamanın içinde olmak isteyen kişi olmasının, otobiyografinin bir düzen ya da yapı dayatmayışının kanıtı olduğu söylenebilir. Aksine içinde bulunduğu kültürde sembolik karşılı̆ıını aramaktadır. Otobiyografiler, önceden fark edilmemiş ya da örtük kalmış yapıları ve anlamları ortaya çıkarmakta ve yaşamı dönüştürerek başka bir seviyeye taşımaktadır” (Crossley, 2000: 537).

\section{Dönüştüren ve Yeniden Var Eden Otobiyografi}

Jenn Stephenson, Performing Autobiography: Contemporary Canadian Drama (2013) adlı kitabında, gerçek dünyaya ait kişilerin tarihe dayalı gerçekliklerini konu eden otobiyografiyi performans bağlamında kurgusal dünyaya aktararak yeniden kavramsallaştırmıştır. Stephenson'a göre otobiyografi sadece durağan, önceden varolmuş yaşam deneyimlerini takip etmek ya da kayıt etmekten çok daha fazlasıdır. Stephenson'a göre gerçekte, öznesinin mükemmel bir portresini çıkarmak olarak kabul edilecekse, otobiyografi imkansız bir edimdir. "Kendinle ilgili gerçeği anlatmak, benliği bütün bir özne olarak inşa etmek sadece bir fantezidir. Fakat bu imkansızlık otobiyografiyi varolmaktan alıkoyamayacaktır" (Lejeune, 1989: 131-132). Stephenson, bir yaşam öyküsünün her zaman tamamlanmamış olması gerektiğini söylemiştir. Ona göre yaşam öyküsünde olaylar seçilmekte, şekillendirilmekte ve sıralanmaktadır. Diğer olaylar unutulmakta, çıkartılmakta ve bilinçli olarak dışarıda bırakıımaktadır. Dolayısıyla "otobiyografi her daim gerçek dünya temsili ve kurgusal ikizi arasında kaçınılmaz boşluğun eşlikçisi olan kurgusal bir yapılanmadır” (2013: 3).
Otobiyografi ister yazılsın isterse sahneye taşınsın bu gerçek ve kurgusal iki benlik birbiri içine karışacaktır. Otobiyografi yazarının ${ }^{1}$ geçmiş deneyimi şimdinin eylemine dönüşecektir. Yazar-özne yani oyuncu, kurgusal hikayesini performans aracılığıyla yeniden yaşayacak, yaşantının üzerinden tekrar geçecektir. Stephenson'un, cennetteki küçük bir Tanrı gibi kendi yaşamı üzerinde süzülmeye benzettiği otobiyografik performans, geçmiş deneyimlerin ziyaret edilmesi ve canlanması için bir katalizör görevi üstlenmektedir (2000: 4).

Otobiyografi, basitçe 'ben buradayım ve bu benim yaşamım' demenin bir yolu olarak kabul edilebilir. Performansın kendisinde saklı olan bir varolma yönelimidir. Performansa içkin bir yaratıcılıktır. "Çünkü yazar, yabancılaşmış ya da marjinalleşmiş benliği, değişken bir metnin yumuşak gövdesinde, karşıt bir anlatıma imkan veren yarı kurgu bir protagonist olarak ortaya çıkıp, baskın kültürün edimlerine ve değerlerine baş kaldıran, yeniden canlanmış bir özneye dönüştürebilir" (Henke, 2000: xvxvi). Bu durumda otobiyografinin dönüştürücü gücü her şeyin önüne geçecektir. Geçmiş, şimdi ve gelecek, bütünlüklü bir zaman algısı içinde bir araya gelecek ve ölümü ilan edilen özne yeniden hayata gelecektir.

Stephenson, doğrudan ve dolaysız otobiyografinin peşinden gitmiştir. Tiyatro metnini meta-otobiyografik bir nesne olarak ele almıştır. Gerçek dünyanın gerçek bilgileriyle işi yoktur. Kurgusal otobiyografi içinde yardıma ihtiyacı olan ve yeniden doğmaya aday bir özne vardır. Stephenson, otobiyografiyi gerçek dünya ve kurgu dünyanın karıştığı bir üçüncü dünya olarak belirlemiştir. Yazar-özne olarak adlandırdığı kimse yaşam öyküsünü yeniden yazan kişidir. Kurgu dünyada anlatıc kimliğine bürünen yazar-özne en nihayetinde performans için bir protagonist karakter ortaya çıkaracaktır. Sadece yazar-özne olarak adlandırılan ilk anlatıcı gerçek olan birinci dünyaya aittir. Diğer alt versiyonlar çeşitlendikçe silikleşmekte, orijinale benzerliği seyrelmektedir. Gerçek dünyaya ait özneyi her anlatan, performansı esnasında eklemeler çıkarmalar yapıp, olayları yorumlayacaktır. Reddettiği, yanlış hatırladığı ya da öyle görmek istediği için ayıkladığı deneyimler, özneyi dönüştürecek bir başkası haline getirecektir (2013: 11-12). 


\section{Öldürmenin Otobiyografisi: Gerçek Easterman Kim?}

Aslıhan Ünlü, Biyografi ve Biyografik Dram (2015) adlı kitabında, oto/biyografinin dram sanatıyla ilişkisini gerçekliğin hatırlanması ve anlatılması temeline oturtur. Otobiyografinin merkezindeki öznenin gerçeklikle ilişkisinin anlatıya dönüşme serüvenini, tarih öncesi dönemden yirminci yüzyıla dek ortaya koyar. Anlatı, çağlar boyunca öznesiyle birlikte değişmiştir. Yirminci yüzyıla gelindiğinde ise anlatının oldukça değiştiğini vurgulayan ünlü, otobiyografi ve buna bağlı türlerin, büyük anlatıların geçerliğini yitirmesi, tüm sistemlerin bir söylem ve dil olması, öznenin kendi yeterlilikleri ve tercihleriyle değil söylemlerle belirlendiğinin kabul edilmesinden oldukça etkilendiğini söyler. Ayrıca bütünlüklü öznenin ölümünün gerçekleştiğini ve her anlatının metinselleştiği anda kurgusallaştı̆̆ını da ifade eder (2015: 48-59).

Öznenin dönüşsmesine hizmet eden, geçmiş ve şimdi arasında bütünlüklü bir anlatının kurulması için devreye giren performanstır. Yazar-özne, anlatıcı ve protagonist birleşerek tek bir 'ben' yaratmak zorundadır. üçü de ontolojik bağlamda tek bir 'gerçeklik' için varolacaklardır. Çünkü özne bu süreçte birkaç farklı ontolojik versiyona bölünmektedir. Anthony Horrowitz'in Ermişler ya da Günahkarlar oyunu, iki farklı gerçekliğin bir arada olduğu bir metindir. Oyun bilinen geleneksel tanımıla bir otobiyografik oyun değildir. Fakat Stephenson'ın yeniden kavramsallaştırdığı otobiyografi için ilginç bir örnektir.

Ermişlerya da Günahkarlar asıl gerçek ve görünen gerçek karşıtlı̆ı üzerine kurulmuştur. Asıl gerçek Stephenson'ın belirlediği gerçek bilinen dünya, görünen ise kurgu olarak adlandırdığı dünyadır. Otobiyografik performansın kendini gösterdiği yer ise işte tam olarak bu iki dünyanın birbirine karıştı̆̆ üçüncü dünyadır. Stephenson bu üç dünyanın işleyişini şu sözlerle açıklar, "Bizim yaşadığımız asıl dünyada ikamet eden gerçek-dünya öznesi, yazar olmaya karar verir ve ilahi bir edimsel yaratım halinde kurgusal dünyada ikamet eden ve kendisinin yerine, iç içe geçmiş üçüncü dünyanın karakter-protagonist sakinini yaratan bir oyuncuanlatıcıya hayat verir" (Malina, 2002: xi). Stephenson, bu giderek çoğalan kurgusal karakterlerden otobiyografinin sadece ilk öznesinin sağlam şekilde gerçek dünyaya bağlı olduğunu ve her alt versiyonun, orijinal özneyle benzerliğinin azaldığını, her yaratıcının çıkartıp eklediği, vurguladığı ya da görmezden geldiği şeylerle ilgili seçimler yaptığını söylemiştir (2013: 12).

Mark Styler, Suffolk'ta bir akıl hastanesine gelip Easterman adlı seri katille ilgili yazacağı kitap için röportaj yapmak isteyen bir cinayet romanı yazarıdır. Bunun için Dr. Farquhar ve hemşiresi Plimpton'ı ikna etmesi gerekmektedir. Fakat yaşanan olay iki doktor tarafından yürütülen bir psiko-drama seansıdır. Styler aslında Easterman'dir. Plimpton Dr. Farquhar, Dr. Farquhar ise Dr. Karel Ennis'tir. Ennis, psiko-drama tekniğiyle hastanedeki hastaların davranışlarının nedenlerini ortaya çıkarmaya çalışan bir psikologdur. Bu oyunda geleneksel bir otobiyografik değil, Stephenson'ın belirlediği üzere, kurgusal ve edimsel bir otobiyografik düzen görülmektedir. Benliğiyle bağları kopmak üzere olan bir karakterin, yeni bir benlik ile gerçek benliğine giden bir yol oluşturmaya çalıştığı anlaşılacaktır.

Oyunun gerçek dünyaya ait yazar-öznesi seri katil Easterman'dir. Her şeyiyle bu ilk dünyanın bir parçasıdır. Şimdilerde hatırlayamadığı ya da zaman içinde yitirdiği benliğinin kökleri gerçek dünyadadır. Fakat o, Mark Styler adlı bir roman yazarı olmayı seçerek yaşam öyküsünü ikinci yani kurgusal dünyaya aktararak kendine anlatıcı yeni bir benlik yaratmıştır ve bu yeni kişinin özelliklerini oyun boyunca kendisi belirlemeye çalışacaktır. Gerçek ve kurgu dünyanın iç içe geçtiği üçüncü dünya ise akıl hastanesindedir. Bu dünyada işler bir miktar karışıktır. Easterman'in artık gerçek dünyada kalan benliği hakkında bilgi sahibi olan asıl kişi Dr. Karel Ennis, Styler rolündeki Easterman karşısında bir süre Dr. Farquhar rolünü sürdürürken, bir süre sonra aslında Easterman olduğunu söyleyerek edimsel bir yeniden yaratım süreci başlatmaktadır. 0 ana kadar sadece Easterman'in yaşam öyküsünü şekillendirmeye uğraşan Styler, artık yitirdiği benliğinin Easterman olduğunu iddia eden Dr. Farquhar'da varoluşunu izlemeye başlayacaktır. Easterman'in yarattığı Styler karakteri anlatıcı rolüyle, sorduğu sorularla, iç içe geçmiş dünyanın protagonistini yaratmıştır. Artık ne yitirdiği esas benliği ne o anı yaşayan kurgusal benliği işe yarar haldedir. Üçüncü ve 
olaylara hakim protagonist, Dr. Farquhar'in performansındaki Easterman'dir. Easterman'e kaybettiği benliğini hatırlatmak için performansın gücünü kullanacaktır. Bu noktada Styler, kendisi hakkında bilgi toplamak bahanesiyle Dr. Farquhar'e sorular soracaktır. Belki önceki seanslardan belki de kendi hafızasının silik parçalarından bir araya getirdiği kişisel bilgilere sahip olmasına rağmen Styler, eksik parçalar için Dr. Farquhar'ın yardımına muhtaçtır.

Styler aslında Dr. Ennis'e ait odada, Dr. Farquhar ile konuşmayı beklerken, bir ses kayıt cihazı kullanarak mekanı tarif eder. Suffolk'ta kırsalda bir akıl hastanesinde olduğunu düşünmektedir. ülkenin en ünlü akıl hastanesi olarak tanımladığı Fairfields'e davet üzerine gittiğini söyler. Oysa bulundukları yer Vauxhall Londra'dır. Ofisin içindeki nesnelerin oldukça kafa karıştırıcı ve garip olduğunu kaydeder. İlk defa geldiği bir yerden ziyade, uzam algısıyla ilgili bir sıkıntı yaşayan takıntılı bir tip gibi görünmektedir. Fakat yazar rolü, ona farklı olabilme özgürlüğü tanımaktadır. Kendinden oldukça emin, özgüvenli bir adam görünümündedir. Dr. Farquhar odaya geldiğinde ne kadar yoğun bir gün geçirdiğinden yakındıktan sonra "Bağışlanması zor bir durum olduğunu biliyorum, fakat siz şurada, karşımda duruyorsunuz ve kim olduğunuz hakkında en ufak bir fikrim bile yok benim" (2005: 3) diyerek Styler'ı yaratıcı olduğu yazar-özne rolünde serbest bırakır. Styler kendini tanıtır. Karşılıklı kısa bir sohbetin ardından hakkında kitap yazacağı kişinin Easterman olduğunu söyler. Dr. Farquhar şaşırmıştır. Psiko-drama seansında, Easterman'in benliğini bulması ve işlediği suçları hatırlaması için kurulan bu oyunda Easterman'in kendisi hakkında araştırma yapıyor oluşu Farquhar’ı sevindirmiştir.

Styler kendisinden bahsetmeye başlar. Anlattığı öykünün Easterman'in yaşam öyküsüyle ilgisi yoktur. Aksine Styler, Easterman'in yaşam öyküsünün peşinde bir yazardır. Şimdinin içinde otobiyografik bir performans sergiliyordur fakat anlattığı şeyler Styler karakterinin kurgulanmış geçmişi ve şimdisidir. "Anlatı, biz yaşam öykümüzü anlatırkenki deneyimlerden doğmaktadır; buna karşııı, deneyim deposu - benlik - sadece anlatı sayesinde şekillenmez aynı zamanda da yaratılır" (Bruner, 1987: 12). Yapısalcı Bruner, zihnin başlıca görevinin dünya yaratmak olduğunu savun- muştur. Sanatın ya da tarihin de bir çeşit dünya yaratma işi olduğunu ve anlatının da bir dünya yaratma şekli olduğunu ve bu bağlamda otobiyografinin de bir yaşam yaratma şekli olduğunu ifade etmiştir (1987: 13). Bruner'in benliğe yaklaşımının en ilginç yanı ise yaşamın kendisi diye bir şey olmadığını iddia etmesidir. Yaşam denilen şeyin insanın hayal gücüne bağlı olduğunu yaşadıkça ve anlatıldıkça oluştuğunu düşünmektedir.

Aynı şey kurgu karakterler için de geçerlidir. Bu karakterler, kelimelerle şekillendirilen ve performansın kendisiyle var olan yaşamlara sahiptirler. Easterman de Styler olmayı tercih etmiş, kelimeleri kullanarak yaşam öyküsünü anlatmaya başlamıştır. Stephenson, kurgusal karakterlerin oto/biyografiyi ya da kendi deyimiyle meta-oto/biyografiyi deneyimlediklerini söylemiştir. Bu karakterler bir anlamda kendi inşa süreçlerinin uygulanabilir bir tekrarını yapmaktadırlar. Fakat birinin benliği edimsel otobiyografiye bağlıysa, Stephenson'a göre anlatıyla yapılanan kurgusal benliğin de hafıza kaybı ya da anlatısal engellerle bozulma ya da zarar görme gibi hassasiyetleri olacaktır (2013: 24). Örneğin Styler, Easterman hakkında sahip olduğu bilgileri Dr. Farquhar’la paylaşmaya başladığında, Dr. Farquhar, Easterman'in olayları değiştirdiğini farkeder. Belli yerlerde müdahalede bulunur. Styler, Easterman'i annesini çok seven, erken yaşta babasını kaybeden bir genç gibi tarif eder. Oysa annesini de babasını da vahşice öldüren Easterman'in kendisidir. Easterman'in, Styler olarak Easterman'in yaşam öyküsünün ayrıntılarını daha iyicil yapışı Taylor'un yukarıda bahsedilen, insanın yaşam öyküsünde 'iyi' olanla ayrıntılarla ilişkilendirip bu ayrıntılara öne çıkarma eğilimini akla getirmektedir. Styler, Easterman'i daha hoşgörüyle yumuşak bir çizgiye çekerken, Dr. Farquhar, Easterman'in yaşam öyküsünün sert ve acımasız yanlarını ortaya koymaktadır. Yaşadığı hayatın yaşamaya değer olması için ilgi çekecek bir hayat yaşamak istemesine dikkat çeker. Ona göre insanlar, iyi olanı değil aksine kötü olanı hatırlamaktadır. Çünkü iyi olmak kolay, kötü olabilme ise zordur. Styler'ın anlatımına göre Easterman zor olanı başarmıştır.

Gerçek dünyaya ait yazar-öznenin ontolojik alt versiyonlarının her seferinde silikleşeceğinden bahsedilmişti 
ve bu Easterman için de gerçekleşmektedir. Oyunun başında Easterman'in, Styler rolüyle, hakkında kitap yazdığı bir başka seri katil Chikatilo'dan bahsederken, aslında kendisinden bahsettiği anlaşılır. Muhtemelen bir önceki seansta kendisi için Chikatilo karakterini seçmiştir. Çünkü kurbanlarına işkence, tecavüz ve onların organlarını ayırmak ve hatta bazen yemek, Easterman ve Chikatilo'nun ortak özellikleridir. Easterman yitirdiği hafızası için her seferinde yeni bir edimsel otobiyografi sahneleyerek kaybettiği gerçek dünyadaki benliğine ulaşmaya çalışmaktadır.

Styler, Dr. Farquhar ile karşılıklı bir şekilde Easterman'i yeniden yapılandırmaktadır. Styler Easterman'le ilgili bir şey söylediğinde, Dr. Farquhar onu düzeltmekte ya da onaylamaktadır. Ellerinde mutlu bir çocukluk geçirdiği halde öncelikle ailesini daha sonra da ondokuz kişiyi öldüren bir cani vardır. Fakat Styler, neden ille de Easterman hakkında yazmak istediğinin cevabını sürekli geçiştirmektedir. Dr. Farquhar üstüne gittikçe geri çekilmektedir. Fakat sonunda "Easterman annemi öldürdü” (2005: 41) diyerek geçerli bir sebep bulur. Aslında bu gerçek benliğinden bir parçadır. Habis bir parçadır ama bunu itiraf etmiş̧tir. Bir roman yazarı olarak, kendisinden bir protagonist olarak söz etse de gerçeği söylemiştir. Özne Easterman, anlatıcı Easterman'in annesini öldürmüştür. Ayrıca Styler, Easterman'in kendi komşusu olduğunu düşünmektedir. Yani annesi, komşuları Easterman tarafından öldürülmüştür. Styler, Easterman hakkında yazarak onu affedebileceğine inanan bir kurban yakını gibi davranmaktadır. Yaptıklarından sonra kendisini affetmeye muhtaç olan bir adamdır Easterman. Fakat kendini anlamak için kendisinden oldukça uzağa gitmesi hatta kendisine yabancılaşması gerekmektedir. 0 da yıllardır seanslarda bunu yapmaktadır.

Easterman yaptıklarının ardından bir travma sonucu içine kapanmıştır. Mahkemede suçunu kabul etmiş fakat pişmanlık belirtmemiştir. Sanatçı olmak istemiştir. Sanat okulunda eğitim almış olmasına rağmen sanatı takdir edilmemiştir. Fakat özel biri olmak istemiştir. Bilinmek, tanınmak ve gerçek dünyada iz bırakmak istemiştir. Styler olarak yiten benliğine yaptığı yolculuk ona hatırlanmak istediğini hatırlatmıştır. Performansı onu, Easterman'in duygularına yaklaştırmıştır. Susan Egan, Mirror Talk: Genres of
Crisis in Contemporary Autobiyography (1999: 5) adlı kitabında otobiyografilerin çözüme ulaşmamış krizlerden ortaya çıktığını söylemiştir. Jean Starobinski ise hayatında radikal bir değişim yaşamamış kimselerin kolay kolay otobiyografi yazmaya yeltenmeyeceklerini ifade etmiştir (1980: 78). "Öykülerimizin çoğu, bir karmaşa, tansiyon ya da kriz kökenlidir” (Kerby, 1991: 63). Easterman da otuz yıldır işlediği korkunç cinayetler konusunda kendisiyle yüzleşememiş bir adamdır. Dolayısıyla aradığı cevaplar için bir öyküye ihtiyacı vardır. Fakat kendisiyle ilgili gerçekleri hatırlayamadığı için yeni benliklerden medet ummaktadır.

Dr. Farquhar protagonist olarak, Easterman'in yaşantısıyla ilgili bilgileri Styler’a aktaran kişidir. Fakat rolü bununla sınırlı değildir. Deliliği ya da bir cani olmanın ne demek olduğunu anlamak isteyen Styler için bir sürprizi vardır. Easterman'e aslında deliliğin görece olduğunu anlatmak için ona deli gömleği giydirmeyi teklif eder. Amacı, Styler'a o gömleği giydiği andan itibaren, karşısında gerçek bir akıl hastası bile olsa dezavantajlı duruma düştüğünü göstermektir. Farquhar, Styler'ın içine düştüğü durumun zafiyetinden faydalanarak adım adım Easterman'in kendisi olduğunu söyleyerek rol değiştirir. Hemşire odaya geldiğinde Styler deli gömleği içinde bağlanmış haldedir. Dr. Farquhar, hemşire Plimpton'a “Easterman'le karşılaşmak istiyordu. Easterman'le karşılaşmayı kendi istedi” (2005: 49-50) diyerek performansına başlar. Dr. Farquhar gerçek Easterman'in ikinci alt versiyonudur. İlk alt versiyon olaylar bu noktaya gelmeden önce, özne Easterman'in anlatcl karakteri Styler ve protagonist Dr. Farquhar'ın birlikte inşa etmeye başladıkları Easterman'in benliğidir. Şimdi sıra iç içe geçen üçüncü dünyanın sakini Easterman'dedir. Bu Easterman gerçek dünyaya ait olanın belki de en değiştirilmiş taklididir. Dr. Farquhar, Easterman'in kişisel tarihine yola çıkarak bir performans sergileyecektir. Bu tam bir otobiyografik performanstır çünkü azılı bir katil gibi rol yapmak zorundadır. Easterman artık ete kemiğe bürünmüştür. Styler oyunun başında Farquhar'e Easterman'in nasıl göründüğünü sormuştur. Kendi yüzünü bile hatırlamayan biri için Dr. Farquhar'in canlandırdığı Easterman, kaybettiği benliğinin ucuz bir kopyasıdır. Fakat ona sürekli kendisini hatırlatmaktadır. Farquhar, Styler'a psiko-drama seanslarının çektirdiği ıztıraptan bahseder. 
FARQUHAR: 0 kahrolası seanslardan bir zamanlar nasıl korktuğumu bir ben bilirim, bir de Allah. Isınma. Eylem. Sarmal yolculuk. Utanç verici bir şeydi! Yani, duyguları dışa vurmamızı istiyorlardı. Her şey ortaya dökülmeliydi. 'Babanı neden öldürdüm?' (Başka bir ses) 'Aman Allah'ım! Babamı öldürdüğümü bilmiyordum!' (Üçüncü bir ses) 'Öldürdün tabii ve benim haberim olmadı; olmalıydı çünkü ben senin babanım!' (2005: 58).

Farquhar'in bu sözleri bile tek bir 'ben' içinde eriyen Easterman'in üç alt versiyonunu anlatmaktadır. Seanslarda kendiyle yüzleşmeye çalışan Easterman, cinayeti neden işlediğini soran sese bir başka sesin cevap verdiği, daha sonra üçüncü bir sesin de konuştuğu bir dünyaya yolculuk yapmıştır. Bu yolla bulmaya çalıştığı benliği ona acı vermiştir. Şimdi de Dr. Farquhar onu bu acı dolu deneyime çağırmaktadır. Dr. Farquhar, Easterman'in annesiyle olan ilişkisinden başlayarak, en ince ayrıntısına kadar bir yaşam öyküsü yaratmaya başlamıştır. İlginç olan Farquhar’in performansı sırasında anlatının gücünden etkileyici biçimde faydalanmasıdır. Gerçekliğinden emin olunamayacak ayrıntılarla Easterman'in hayatını, Easterman'in önünde yeniden canlandırmaktadır. Bahçelerindeki çiçeklerin kokusundan, çok sevdiği köpeğe kadar her ayrıntıyı kullanmaktadır. Annesini çok sevdiğini iddia eden Styler’ın, Farquhar'in Easterman'in hayatıyla ilgili verdiği ayrıntılarla, algısı bozulmuştur. Styler artık ne bildiğinden emin değildir. Üçüncü dünyaya ait protagonist Easterman o kadar gerçektir ki artık gerçek Easterman'in kim olduğunun bir önemi kalmamış gibidir. Aralarında karşılıklı bir yaratım süreci yaşanmaktadır.

FARQUHAR: Hemen, şimdi, her şeyi anlatabilirsiniz bana. Kimse öğrenmeyecek anlattıklarınızı. Aramızda müthiş bir samimiyet kurduk Mark. Yazar ile kahramanı, katil ile maktul arasında kurulan cinsten bir samimiyet. Hep hayal ettiğiniz, ama asla cesaret edemediğiniz şeyleri yapabilir, aklınızdakileri anlatabilirsiniz burada. Çünkü yalnızca siz ve ben varız; ayrıca hangimizin gerçekten deli olduğundan bile emin değiliz (2005: 75)...

Farquhar, Styler ile arasındaki ilişkinin doğasını ortaya koymuştur. Styler, üçüncü dünyaya ait Easterman'in yazarı durumundadır. Yani kurgusal dünyadaki Easterman'nin. Gerçek dünyada kaybolmuş özne Easterman, kurgusal dünyada anlatıcı Styler olarak yeni öyküsünün protagonistini yaratmıştır. Kendi yaşamını protagonist Easterman'den dinlemektedir. Lejeune, otobiyografik birlik prensibini ortaya atan ilk kişi olarak, yazar-özne, anlatıcı ve protagonistin aynı ve öznenin de gerçek bir insan olması gerektiğini belirtmiştir. Böylece yaşam öyküsünün gerçekliği korunmuş olacaktır. Özne öyküyü gerçek dünyada sağlam bir temele oturtacak, anlatıcı ise kendisi ve diğer alt versiyonlar arasında rolden role geçişteki doğruluğu muhafaza edecektir. Bu geçiş esnasında, kurgusal dünyanın gerisindeki gerçek, ayıklamalar ve eklemelerle yeniden yapılanma süreci yaşayacaktır (Eakin, 1985: 3-30).

Farquhar işi ileri götürmüştür. Styler’a Easterman'in ayrıntılarını verdikçe gerçek Easterman'i kendi dünyasına çekmektedir. Easterman'in hırslarını, hayal kırıklıklarını, hıncını, arzularını kullanarak öyle bir dünya yaratmıştır ki Styler'in altında saklanan Easterman ortaya çıkmak üzeredir. Son olarak Hemşire Plimpton'a işkence etmesi hatta onu istediği şekilde öldürmesi için teşvik eder. Sürekli birbirlerine ne kadar çok benzediklerini söylemektedir. Styler'a Easterman hakkında kitap yazmak istemesinin sebebinin, canilerin karanlık duygularına duyduğu yakınlık olduğu yönünde telkinlerde bulunmaktadır. Styler’ı aslında içinde öldürmek isteyen bir cani olduğuna inandırmaya çalışmaktadır. Easterman olmanın ne demek olduğunu deneyimlemesi gerektiğine Styler'i inandırmıştır. Styler, Hemşire Plimpton’ı torbayla boğup öldürdüğünü düşündüğü anda Farquhar yani Dr. Ennis oyunu bozar. Ne olduğunu anlayamayan Styler sadece bir an Easterman olduğunu fark eder. Fakat sonra kendi gerçekliğine döner. Doktorun Easterman'le bu seansları birçok kez yaptığı anlaşılır. Dr. Ennis'in önce Dr. Farquhar ardından da Easterman olduğu performansı, Easterman'e aslında nasıl bir hayat yaşadığını ve kim olduğunu anlatmanın bir yolu olmuştur.

Gelinen son noktada Easterman, geçmişinde saklı şiddeti, Dr. Ennis vasıtasıyla yeniden hatırlar. Oldukça sert bir yöntemle gerçek dünyadaki şiddet, kurgu dünyaya taşınmıştır. Bu da Easterman'in gerçeğini sert bir şekilde algıla- 
masına sebep olmuştur. Kurgusal dünyadaki otobiyografik anlatılarda canlandırılan şiddet, dünyalar arası sınırlar önceki olaylara yapılan göndermelerle hasar gördükçe, yapısal düzeyde tekrar etmektedir. Bu da kurgusal dünyanın güvenliğini riske atmaktadır. Örneğin yazar hikayeye devam etmeme kararı alırsa kurgusal dünya çökecektir (Stephenson, 2013: 16-17). Oyunda Styler’a olan da budur. Geçmişte yaşanan şiddet Dr. Ennis'in kontrolü altında tekrar etmiştir. Şiddetin en yüksek noktasında Dr. Farquhar devam etmeme kararı almış ve oyunu durdurmuştur. Stephenson, bu krizli anların ne kadar yıkıcı olurlarsa olsunlar aynı zamanda dönüştürücü süreçleri tetiklediğini söylemiştir (2013: 17). Fakat oyunun sonunda Hemşire rolündeki Dr. Farquhar, Dr. Ennis'e, bu seansların giderek şiddetlendiğini ve bundan hoşlanmadığını belirtmiştir. Easterman ise seans sonrası odanın içindeki gerçek dünyayla arasına bir duvar örmüş, Mark Styler olduğunu söyleyerek kurgusal dünyasında kalmayı tercih etmiştir.

\section{Sonuç}

Kişi kendi hafızasında zamanda yaptığı yolculukla benliğini her seferinde yeniden inşa etmektedir. Geçmişi düşünüp yeniden hatırlamak, her seferinde farklı ayrıntılara ulaşmak anlamına gelmektedir. Bu bağlamda geçmiş, kişinin bugünü ve geleceği daha farklı algılamasına sebep olacaktır. Yaşam boyu krizler, travmalar ya da büyük değişimler, kişileri yaşamlarını hatırlayabildikleri yerden başlayarak yeniden düşünmeye sevk edebilir. Bu çoğu zaman, yaşam öyküsünde bugün olanlara anlam vermek, sebepleri ortaya koymak için atılan bir adımdır. Anlatı insan yaşamını şekillendirirken, geçmişin izleriyle şimdiyi düzenlemektedir. Otobiyografi tiyatroda geleneksel biçiminden sıyrılarak, öznenin kurgusal alt versiyonlarını yaratması ve kurgusal karakterlerin, performansın edimsel potansiyelinden faydalanarak yeni benler hayal edebilmesini sağlamaktadır. Bu alternatif ontolojik versiyonlar esas öznenin yitirdiği ya da yabancılaştığı benliğini geri çağırmaktadır.

Easterman, kendi ailesi dahil birçok kişiyi vahşice katletmiş bir seri katildir. Yakalanıp tımarhaneye kapatılmasının üzerinden yirmidokuz yıl geçmiştir. Dr. Karel Ennis'in psiko-drama seanslarına zorla katılan Easterman, kendisinin o vahşi eylemlerin sorumlusu olduğunun bile farkında değildir. Seanslar dışında tam bir sessizlik içindedir. Dr. Ennis'in, Easterman'in kendisiyle yüzleşmesi ve gerçekliğinin farkına varması için düzenlediği seanslardan biri olan oyun, Easterman'in üç versiyonuna ev sahipliği yapmaktadır. Özne Easterman, anlatıcı Mark Styler rolüne bürünmüş ve Easterman rolündeki Dr. Ennis’le karşı karşıya kalmıştır. Anlatıcı (Styler) ve protagonistin (sahte Easterman) karşılıklı olarak gerçek dünyaya ait ama o seansta olmayan özne Easterman'e referansla oluşturdukları yaşam öyküsü performansın gücüyle hayat bulmuştur. Seansın sonunda Easterman sadece bir an gerçek benliğiyle bağlantı kurmuş, Mark Styler rolünden çıkmak istememiştir. Kendini güvende hissettiği yer kim olduğunun, uydurma da olsa farkında olduğu ikinci dünya yani Styler'ın dünyasıdır.

Oyunda görüldüğü üzere, otobiyografik performans gerçek benlik ve kurgusal benlik(ler) arasındaki sınırları kaldırmaktadır. Ermişler ya da Günahkarlar'da olduğu gibi gerçek yaşamdaki şiddeti tekrar çağırma intimali olmasına rağmen otobiyografik performans, karakterin daha iyi bir versiyonunu geleceğe taşıma ihtimaline sahiptir. Anlatı, yaşamın kendisini oluşturan güçtür. Yaşam öykümüzü anlatmak önemli bir kimlik gelişim sürecine hizmet etmektedir. Anıların ve benliğin yitimi, kişinin varoluşuna bir tehdit oluşturacaktır. Bu yüzden kişisel anlatılar, benliğin yegane ihtiyaçlarından biridir. "Otobiyografik performans, marjinalize olmuş ya da görünmez hale gelen kimlikleri görünür kılmaktadır" (Stephenson, 2013: 154). Geleneksel otobiyografiden farklı olarak tamamı kurgusal karakterlerden oluşan otobiyografik performans alanı, izleyicisine bir kişinin hayatına başka bir gözle bakma imkanı tanıyacaktır. Öznenin alternatif versiyonları, benliğin varolma sebebi olan yaşam öyküsünün aslında bir anlatıdan ibaret olduğunu ortaya koyacaktır.

\section{Notlar}

1- Burada yazar, geleneksel olarak kendi yaşam öyküsünü yazan kişi olarak anlaşılmamalıdır. Yazar metin içinde yaşam öyküsü bir yönüyle konu olan karakterdir. Yani öznedir. 


\section{Kaynakça}

Brewer, W. F. (1986). "What Is Autobiographical Memory?", $A u$ tobiographical Memory, 25-49, Cambridge: Cambridge University Press.

Bruner, J. (1987). “Life as Narrative”, Social Research, 54. 1: 11-32.

Carr, D. (1986). Time, Narrative And History, Bloomington: Indiana University Press.

Crossley, M. L. (2000). "Narrative Psychology, Trauma and The Study of Self/Identity”, Theory \& Psychology, Vol. 10(4): 527 546.

Edwards, D. \& Potter, J. (1992). Discursive Psychology, London: Sage.

Eakin, PJ. (1985). Fictions in Autobiography: Studies in the Art of SelfInvention, Princeton University Press.

Henke, S. A. (2000). Shattered Subjects: Trauma and Testimony in Women's Life-Writing, New York: St. Martin's Press.

Horrowitz, A. (2005). Ermişler ya da Günahkarlar, çev: Zeynep Avcı. (Yayımlanmamış oyun metni)

Lejeune, P. (1989). On Autobiography, Ed: P. J. Eakin, Minnesota: University of Minnesota Press.

Malina, D. (2002). Breaking The Frame: Metalepsis and the Construction of the Subject, Colombus: Ohio State University Press.

Neisser, U. (1988). "Five Kinds of Self Knowledge”, Philosophical Psychology 1.1, 35-59.

Ochs, E., Capps, L. (1966). “Narrating Self”, Annual Review of Anthropology 25, 19-43.

Parker, I. (1991). Discourse Dynamics: Critical Analysis for Social and Individual Psychology, London: Sage.

Polkinghorne, D.P. (1988). Narrative Knowing and the Human Sciences, Albany: State University of New York Press.

Potter, J., Wetherell, M. (1987). Discourse and Social Psychology: Beyond Attitudes and Behaviour, London: Sage.

Ricoeur, P. (1986). “Life: A story in Search of a Narrator”, eds: M. Doeser \& J. Kray, Facts and Values, pp. 34-68, Dordrecht: Nijhoff.
Ricoeur, P. (1991). “Life in Quest of Narrative”, ed. D. Wood, Paul Ricoeur: Narrative and Interpretation (pp. 20-33), London: Routledge.

Sarbin, T.R. (1986). Narrative Psychology: The Storied Natire of Human Conduct, New York: Prager.

Stephenson, J. (2013). Performing Autobiography: Contemporary Canadian Drama, Toronto: University of Toronto Press.

Taylor, C. (1989). Sources of the Self: The Making of Modern Identity, Cambridge: Cambridge University Press.

Ünlü, A. (2015). Biyografi ve Biyografik Dram, Ankara: NotaBene Yayınları. 